\title{
"Early transfusion of convalescent plasma in older patients with COVID-19 to prevent disease progression: A structured summary of a study protocol for a randomised controlled trial"
}

\author{
Luciana Teofili ${ }^{1 *}$ D, Raffaele Landolfi ${ }^{1}$, Antonella Cingolani ${ }^{1}$, Andrea Antinori ${ }^{2}$, Jacopo Vecchiet ${ }^{3}$,
} Maurizio Sanguinetti ${ }^{1}$, Antonio Gasbarrini ${ }^{1}$, Tina Pasciuto ${ }^{1}$, Nicoletta Orlando ${ }^{1}$ and Silvia Lamonica ${ }^{1}$

\begin{abstract}
Objectives: The primary objective is to demonstrate that COVID-19 convalescent plasma (CCP) prevents progression to severe pneumonia in elderly COVID-19 pneumonia patients with chronic comorbidities.

Secondary objectives are to demonstrate that CCP decreases the viral load in nasopharyngeal swabs and increases the anti-SARS-CoV-2 antibody titre in recipients.

Trial design: This is a randomized, open-label, parallel group, phase II/III study with a superiority framework. The trial starts with a screening phase II designed with two-tailed alpha $=0.2$. In case of positive results, the trial will proceed in a formally comparative phase III (alpha=0.05).

Participants: Adult patients with confirmed or suspected COVID-19 who are at risk according to CDC definition are eligible. Inclusion criteria are all the following: age $\geq 65$; pneumonia at CT scan; PaO2/FiO2 $\geq 300 \mathrm{mmHg}$; presence of one or more comorbidities; signed informed consent. Exclusion criteria are one of the following: age < 65; $\mathrm{PaO} 2 / \mathrm{FiO} 2$ < $300 \mathrm{mmHg}$; pending cardiopulmonary arrest; refusal to blood product transfusions; severe IgA deficiency; any lifethreatening comorbidity or any other medical condition which, in the opinion of the investigator, makes the patient unsuitable for inclusion. The trial is being conducted at three reference COVID-19 centres in the middle of Italy.
\end{abstract}

Intervention and comparator: Intervention: COVID-19 Convalescent Plasma (CCP) in addition to standard therapy. Patients receive three doses (200 ml/day on 3 consecutive days) of ABO matched CCP.

Comparator: Standard therapy

Main outcomes: A. Primary outcome for Phase II: Proportion of patients without progression in severity of pulmonary disease, defined as worsening of 2 points in the ordinal scale of WHO by day 14.

B. Primary outcome for Phase III: Proportion of patients without progression in severity of pulmonary disease, defined as worsening of 2 points in the ordinal scale of WHO by day 14.

(Continued on next page)

\footnotetext{
* Correspondence: Iuciana.teofili@unicatt.it

${ }^{1}$ Fondazione Policlinico Universitario A. Gemelli IRCCS, Rome, Italy

Full list of author information is available at the end of the article
}

(c) The Author(s). 2020 Open Access This article is licensed under a Creative Commons Attribution 4.0 International License, which permits use, sharing, adaptation, distribution and reproduction in any medium or format, as long as you give appropriate credit to the original author(s) and the source, provide a link to the Creative Commons licence, and indicate if changes were made. The images or other third party material in this article are included in the article's Creative Commons licence, unless indicated otherwise in a credit line to the material. If material is not included in the article's Creative Commons licence and your intended use is not permitted by statutory regulation or exceeds the permitted use, you will need to obtain permission directly from the copyright holder. To view a copy of this licence, visit http://creativecommons.org/licenses/by/4.0/. The Creative Commons Public Domain Dedication waiver (http://creativecommons.org/publicdomain/zero/1.0/) applies to the data made available in this article, unless otherwise stated in a credit line to the data. 
(Continued from previous page)

Secondary outcomes for Phase III: Decreased viral load on nasopharyngeal swab at days 6, 9 and 14; Decreased viremia at days 6 and 9; Increased antibody titer against SARS-CoV2 at days 30 and 60; Proportion of patients with negative of SARS-CoV2 nasopharyngeal swab at day 30; Length of hospital stay; Mortality rate at day 28; Total plasma related adverse event (day 60); Total non-plasma related adverse events (day 60); Severe adverse events (SAE) (day 60).

Randomisation: Treatment allocation is randomized with a ratio 1:1 in both phase II and phase III. Randomization sequences will be generated at Fondazione Policlinico Gemelli IRCCS through the RedCap web application.

Randomized stratification is performed according to age (under/over 80 years), and sex.

Blinding (masking): None, this is an open-label trial.

Numbers to be randomised (sample size): Phase II: 114 patients (57 per arm).

Phase III: 182 patients (91 per arm)

Trial Status: The trial recruitment started on May 27, 2020. The anticipated date of recruitment completion is April 30 , 2021. The protocol version is 2 (May 10, 2020).

Trial registration: The trial has been registered on ClinicalTrials.gov (May 5, 2020). The Identifier number is NCT04374526

Full protocol: The full protocol is attached as an additional file, accessible from the Trials website (Additional file 1). In the interest in expediting dissemination of this material, the familiar formatting has been eliminated; this Letter serves as a summary of the key elements of the full protocol.

Keywords: COVID-19, randomised controlled trial, protocol, elderly, comorbidities

\section{Supplementary information}

Supplementary information accompanies this paper at https://doi.org/10. 1186/s13063-020-04821-1.

Additional file 1:. Full study protocol

\section{Acknowledgements}

The authors warmly thank the blood donor association "Francesco Olgiati Onlus".

\section{Authors' contributions}

$L T, R L, A C, A A, J V, M S, A G$ : study conception and design; protocol writing. TP, $\mathrm{NO}$ and SL: data management and study monitoring. All authors contributed to refinement of the study protocol and approved the final manuscript.

\section{Funding}

Not applicable

\section{Availability of data and materials}

Authors can access data through the REDCap web platform. Data will be available from the authors on reasonable request. Please address the requests to: luciana.teofili@unicatt.it; antonella.cingolani@unicatt.it; raffaele. landolfi@unicatt.it

\section{Ethics approval and consent to participate}

The ethics committee of Fondazione Policlinico A. Gemelli IRCCS approved the study (Prot. N. 0020131/20, May 13, 2020). We certify that this trial has received ethical approval from the appropriate ethical committee as described above. The participants will be adequately informed in clear, simple and understandable words of the technical terms used and will be invited to provide oral or written informed consent. The participants will be provided with a description of the general aims of the research, the methodology and procedures used, the indication of any benefits or possible risks and adverse effects. In addition to consent to participate in the study, all patients should give consent to receive blood products. The consent can be expressed orally if two different witnesses state that the patient was properly informed and fully understood study aim and procedures, and sign the consent.

\section{Competing interests}

The authors declare that they have no competing interests.

\section{Author details}

${ }^{1}$ Fondazione Policlinico Universitario A. Gemelli IRCCS, Rome, Italy. ${ }^{2}$ Istituto Nazionale Malattie Infettive Lazzaro Spallanzani IRCCS, Rome, Italy. ${ }^{3}$ Presidio Ospedaliero S.S. Annunziata, ASL Lanciano -Vasto-Chieti, Università di Chieti, Chieti, Italy.

Received: 13 October 2020 Accepted: 16 October 2020

Published online: 22 October 2020

\section{Publisher's Note}

Springer Nature remains neutral with regard to jurisdictional claims in published maps and institutional affiliations.

\footnotetext{
Ready to submit your research? Choose BMC and benefit from:

- fast, convenient online submission

- thorough peer review by experienced researchers in your field

- rapid publication on acceptance

- support for research data, including large and complex data types

- gold Open Access which fosters wider collaboration and increased citations

- maximum visibility for your research: over $100 \mathrm{M}$ website views per year

At BMC, research is always in progress.

Learn more biomedcentral.com/submissions
} 